\title{
Tracing textile cultures of Italy and Greece in the early first millennium BC
}

\author{
Margarita Gleba*
}

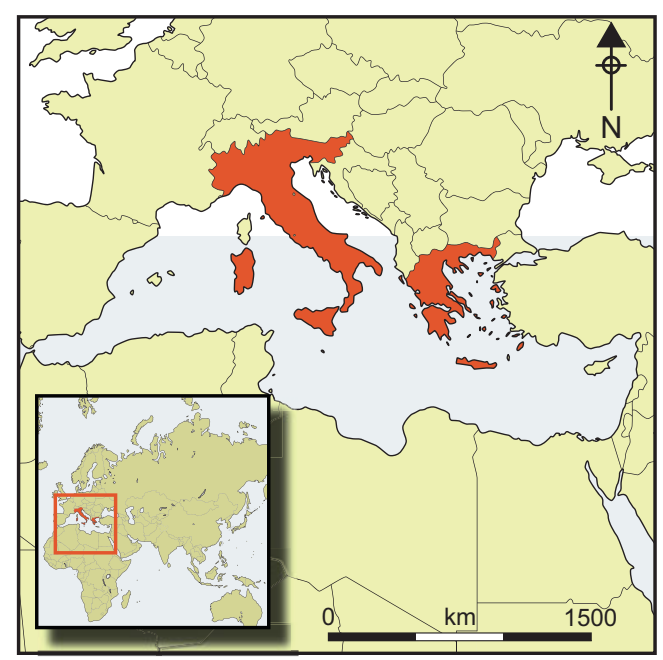

Archaeological textiles are relatively rare finds in Mediterranean Europe, but many fragments survive in a mineralised form. Recent analysis of Iron Age textiles from Italy and Greece indicates that, despite the use of similar textile technologies at this time, Italy shared the textile culture of Central Europe, while Greece largely followed the Near Eastern traditions of textile production. This research greatly expands our current understanding of the regional circulation of textile technological knowledge and the role of textiles in ancient societies.

Keywords: Italy, Greece, Iron Age, textiles, textile cultures

\section{Introduction}

Despite their universally recognised value as the most important carriers of individual and group identity, textiles are rarely, if ever, included among the cultural indicators of the ancient societies of Mediterranean Europe-a lacuna ostensibly resulting from the unfavourable conditions for organic material preservation in the region. When textiles are considered, Italy and Greece are generally assumed to have had similar technological and aesthetic traditions of textile production during the first millennium BC. But what is the evidence for this?

Central and Eastern Mediterranean Europe between 1000 and 400 BC was an area of dynamic change, characterised by the movement of people and goods, the production of wealth, the rise of urbanism, mobility and craft specialisation. The role of elites in these processes through social networks of gift and commodity exchange, and control of land and natural resources, has been amply demonstrated (e.g. Riva 2010). The contribution of

\footnotetext{
* McDonald Institute for Archaeological Research, University of Cambridge, Downing Street, Cambridge CB2 3ER, UK(Email:mg704@cam.ac.uk)
}

(C) Antiquity Publications Ltd, 2017. This is an Open Access article, distributed under the terms of the Creative Commons Attribution-NonCommercial-NoDerivatives licence (http://creativecommons.org/licenses/ by-nc-nd/4.0/), which permits non-commercial re-use, distribution, and reproduction in any medium, provided the original work is unaltered and is properly cited. The written permission of Cambridge University Press must be obtained for commercial re-use or in order to create a derivative work. 
economic activities related to metal, ceramic and agricultural production to the urbanisation of Iron Age Italy and Greece has long commanded the attention of archaeologists and historians. The role of textiles, both in terms of wealth generation and subsistence, has, however, not been investigated.

The significance of the production and consumption of textiles in the development of city-states (as clothing, elite regalia, trade and exchange items), and the implications of this for other aspects of the economy, such as the use of farm land, labour resources and the development of an urban lifestyle, cannot be overestimated. The state archives of the Bronze Age urban states of Mesopotamia and the Aegean during the third and second millennia BC provide abundant evidence for the importance of textile production and consumption in the formation of the political systems synonymous with urbanisation (McCorriston 1997; Killen 2007). In the absence of similar written evidence for the first millennium BC, we must turn to archaeological evidence for answers. The first step is to understand what type of textiles the Iron Age societies of Italy and Greece wanted and produced - that is, to define their textile cultures.

Susanna Harris recently proposed the concept of 'cloth culture' based on the idea that all societies use cloth-type materials, but the way they do so is culture-specific (Harris 2012: 62). This study included not only textiles, but also animal skins, and considered both materials and their use when comparing cloth cultures of Bronze Age Scandinavia, Central Europe, the Aegean and Egypt. Although this paper focuses purely on textiles, use of the term 'textile culture' is inspired by Harris's approach, in that it is defined here not only in terms of raw materials and techniques, but also in terms of cultural preferences determined by the specific traditions, aesthetics and values of an individual society.

This ongoing analysis of several hundred textile fragments provides, for the first time, a much more detailed definition of textile cultures in Italy and Greece during the first half of the first millennium BC, a period of considerable socio-economic changes that led towards social stratification, urbanisation and unprecedented long-distance interactions. These new data help us to understand the choices in technology made within these regions, and to demonstrate cultural similarities with other broader areas.

\section{Methods and materials}

The data required to define a textile culture of a particular region includes structural textile parameters, such as thread diameter in warp and weft (expressed in millimetres); thread twist direction in warp and weft ('z' for clockwise; 's' for counter-clockwise; 'i' for no discernible twist; ${ }^{*}$ ' for splicing; Figure 1); the type of textile weave or binding (plain weave/tabby or twill; Figure 1); thread count (expressed in number of threads per centimetre) in warp and weft, which indicates cloth quality; the presence of edges and other diagnostic features; and material (wool, flax and the like).

Despite unfavourable environmental conditions, Iron Age textiles do survive in the northern Mediterranean. Among the best-known examples are the almost completely preserved semi-circular mantles and tunic-like garments from Verucchio, on the Adriatic side of northern Italy (Stauffer 2012). While such organic preservation is relatively rare, mineralised textile traces on metal objects in burials are more common than previously (C) Antiquity Publications Ltd, 2017 


\section{THREAD TWIST DIRECTION}

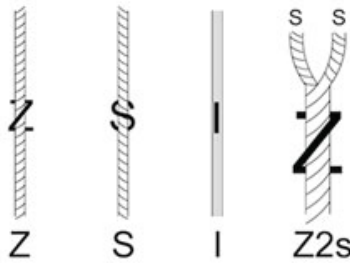

Z - Clockwise

S - Counterclockwise

I - No discernible twist

*- Splicing

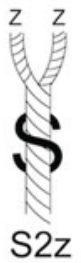

\section{THREAD DIAMETER (mm)}
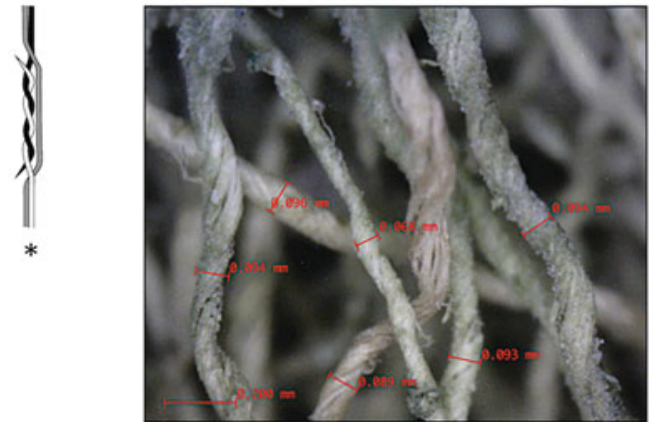

\section{WEAVE}

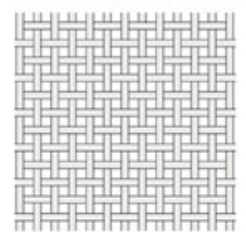

Plain weave or tabby

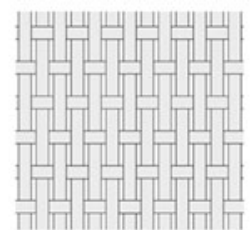

Warp-faced tabby

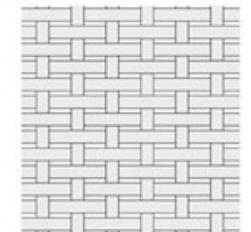

Weft-faced tabby

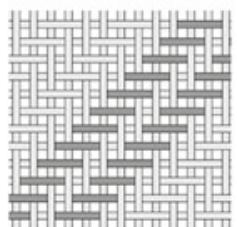

$2 / 2$ diagonal twill

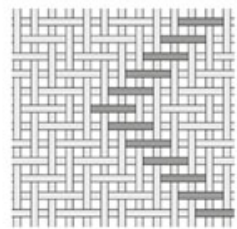

2/2 diamond twill

Figure 1. Structural textile parameters (image: Vicki Herring \& Margarita Gleba).

recognised (Figure 2). Mineralised formations are created when metal (copper alloy or iron) corrosion products form casts of, or around, fibres, thereby retaining their external morphology and size almost unaltered (Chen et al. 1998). They are usually found on

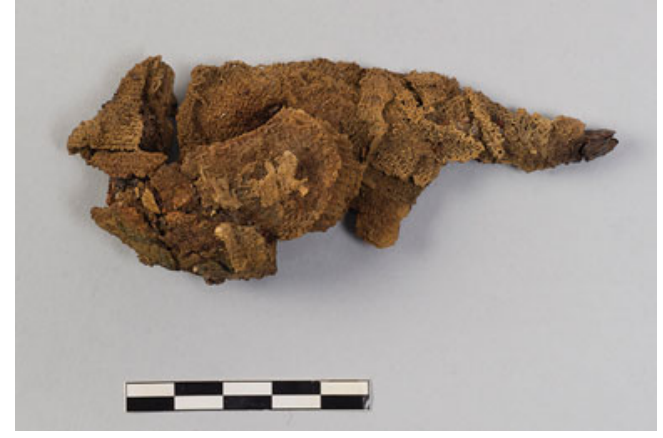

Figure 2. An iron dress pin with several different mineralised textiles preserved in layers (image: Margarita Gleba). iron and bronze grave goods that were deposited in close proximity to, or intentionally wrapped in, textiles (Gleba 2008, 2014a); they are particularly common on personal ornaments such as pins and belts. Even when minute, these traces can provide a considerable amount of information concerning ancient textile structure, including their various technical parameters. Using advanced methods, such as scanning electron microscopy, it is often possible to identify the nature of the fibre (Figure 3).

\section{Results}

The study area encompasses the territories of modern Italy and Greece, covering the period between 1000 and $400 \mathrm{BC}$. The material reviewed here comes primarily from funerary 

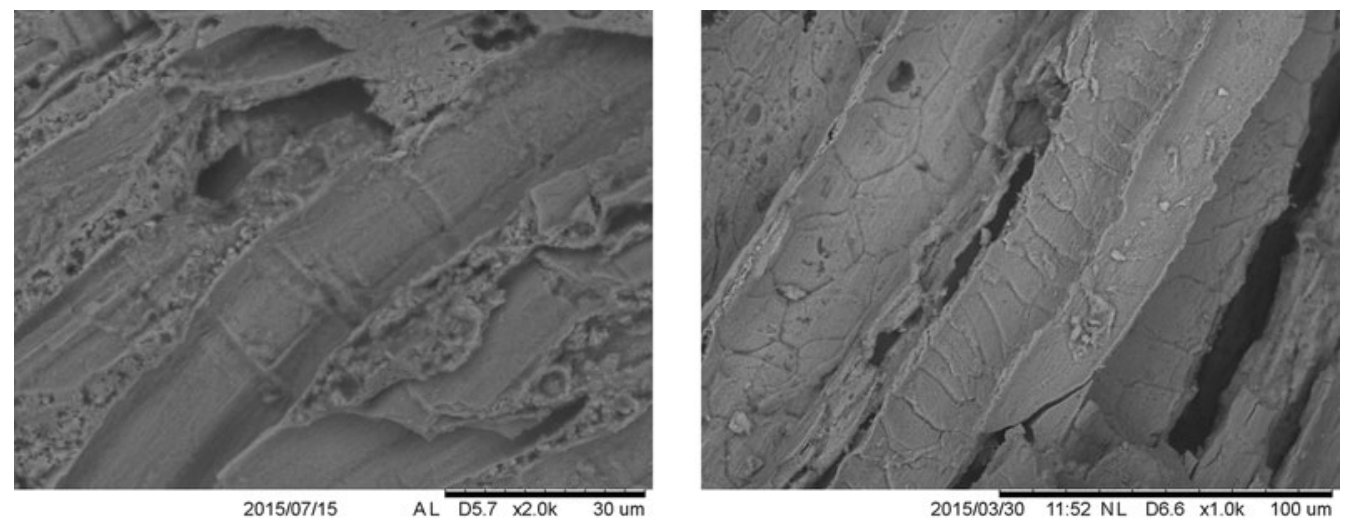

Figure 3. SEM micrographs of: left) wool; right) flax fibre casts in Iron Age mineralised archaeological textiles from Italy (images: Margarita Gleba).

contexts, with only a few fragments excavated in settlements, and a special group that was found frozen in the Italian Alps. This inevitably creates a bias towards high-status textiles and those probably used for garments or wrapping rather than for other, utilitarian purposes, such as furnishings and sails. The geographic and chronological distribution of finds is uneven; certain areas (e.g. the Etruscan cultural area in Italy, and Attica in Greece), and certain periods (e.g. the Orientalising period, 725-580 BC, in Italy) are better represented, due to peculiarities of burial customs and regional excavation and conservation histories.

The total number of textiles recorded to date is 192 for Italy, and 107 for Greece. The material from the two regions is compared in terms of weave and other structural parameters (Figure 4).

\section{Textile culture of Italy 1000-400 BC}

Analysis of textile fragments from Italy demonstrates a variety of weaves and techniques, several of which are closely associated with the European Iron Age (Figure 4). Plain weave textiles or tabbies in single, primarily z-twisted yarns are generally common. A tabby is one of the earliest loom-woven structures, being the simplest textile binding attainable with two thread systems on a loom, with passive warp and active weft threads alternating one over one in each direction (Figure 5). Balanced tabbies - those with approximately the same number of threads per centimetre in weft and warp-were commonly used in graves as shrouds or as wrapping material around burial gifts (Gleba 2014a).

In addition to this more common balanced type, special tabbies have also been identified. A small group is represented by warp-dominant tabbies in flax, which have more warp than weft threads per unit of length and have been woven in spliced yarn (Gleba \& Harris in press).

A much larger group consists of wool weft-faced tabbies, which have at least twice as many wefts as warp threads per unit of length, and they are usually so tightly packed that the warp becomes invisible (Figure 6). Another common characteristic of this group of textiles (C) Antiquity Publications Ltd, 2017 


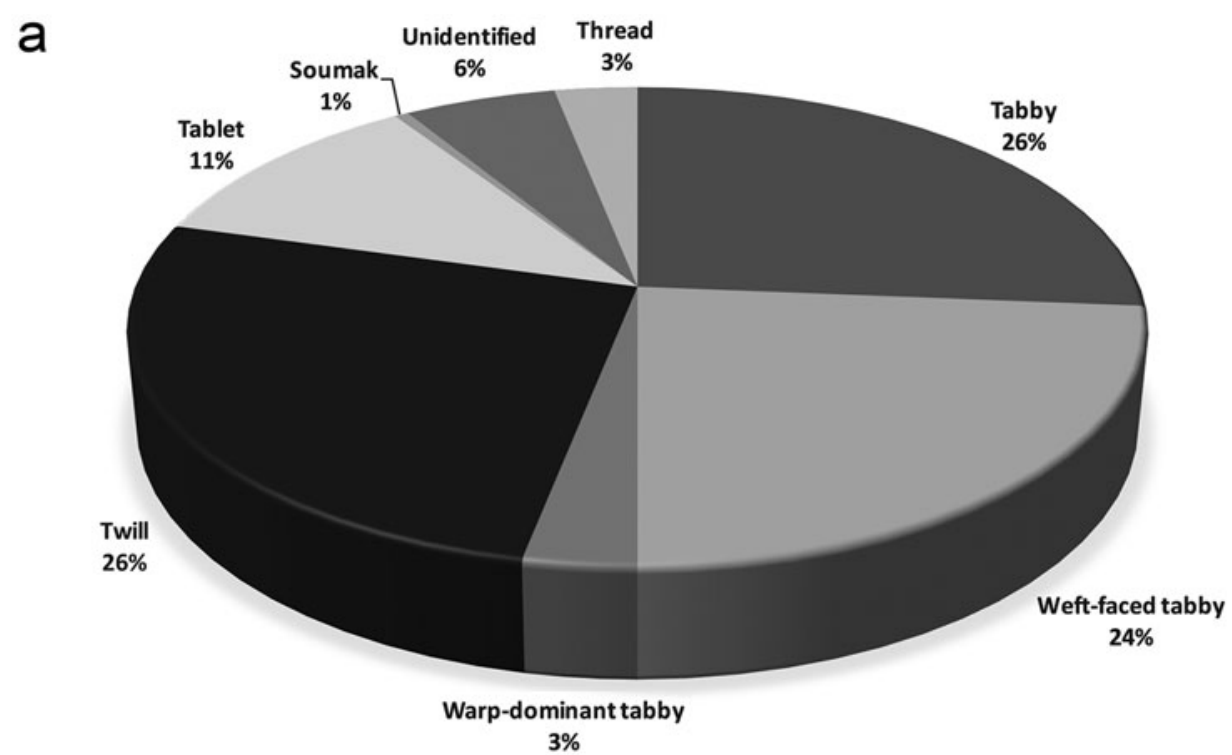

b

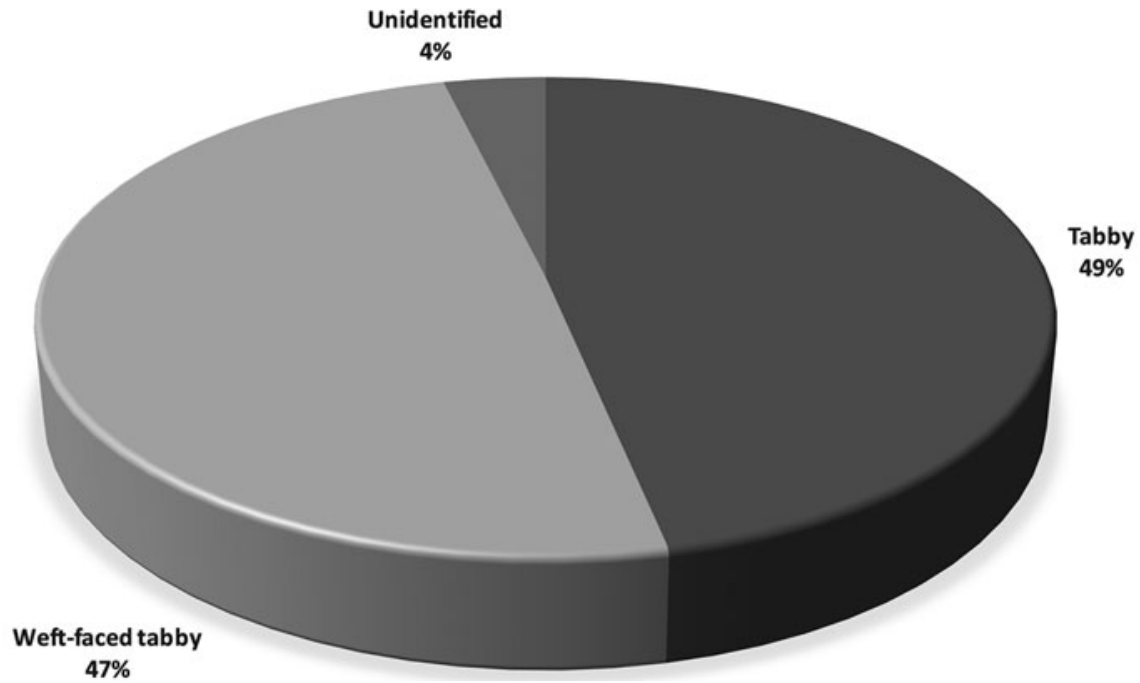

Figure 4. Different weave percentages in: a) Italy; b) Greece (images: Margarita Gleba).

is that while the warp threads are hard twisted, the weft yarn has barely any twist. These textiles have been found in the Abruzzo region (the majority of textiles in this group come from a single site, Alfedena), an area that was culturally associated with the Adriatic basin during the Iron Age. Weft-faced tabbies have also been found in post-colonial contexts of southern Italy and in a few exceptionally rich Etruscan and Latial burials, which contained extraordinary quantities of eastern imports. The significance of this is discussed below.

Over a quarter of the Iron Age textiles from Italy investigated thus far, however, fall into a different category, and have been found throughout northern and central Tyrrhenian and

(C) Antiquity Publications Ltd, 2017 

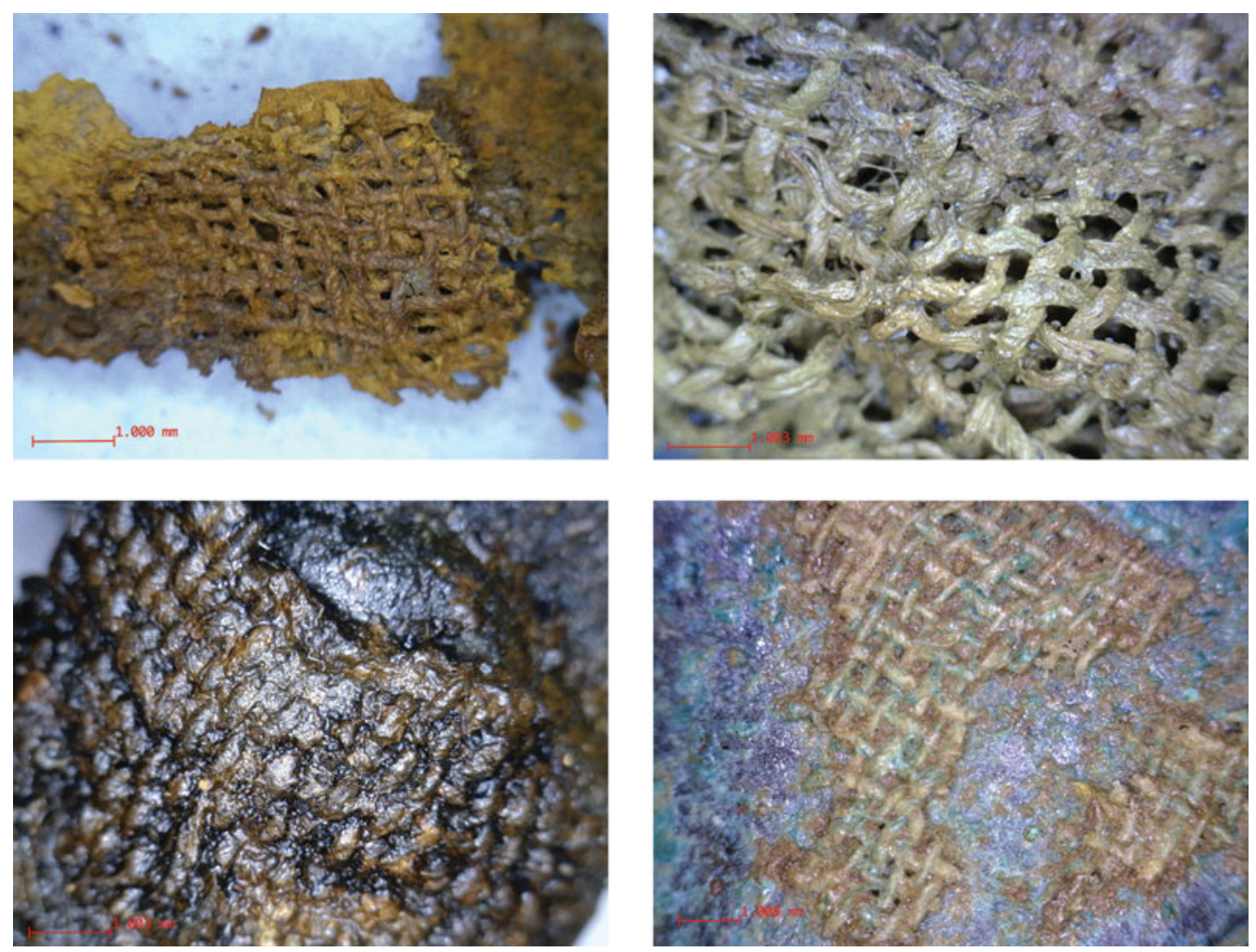

Figure 5. Selection of tabbies from Italy: top left) Civita Castellana, seventh century BC; top right) Orvieto, sixth century $B C$; bottom left) Tarquinia, seventh century BC; bottom right) Vulci, sixth century BC (images: Margarita Gleba).

southern Italy. These are wool textiles woven in balanced 2/2 twill weave, which have tabletwoven borders. In a twill, the horizontal weft threads pass over and under vertical warps in a regular staggered pattern, each row being stepped to one side of the row above, creating a diagonal effect (Table 1; Figure 7). Production of a twill requires a different set up on a loom, with the warp divided into four, rather than two, sets of threads. These would have been moved in specific sequences to create the variants, such as plain diagonal, warp- or weft-chevron, broken and more complex diamond and dogtooth twills.

These twills are often spin or shadow-patterned, i.e. made using alternating groups of threads twisted in opposing directions in both warp and weft, which would have created a textured appearance (Grömer et al. 2013: 81). The quality of these textiles is rather homogeneous. Threads, which are generally hard-twisted, have diameters ranging from $0.2-0.5 \mathrm{~mm}$, and thread counts are usually $10-30$ threads per centimetre.

Italic twill textiles often have tablet-woven borders (Figure 8). Tablet weaving involves passing threads through holes in the corners of (usually) square tablets, which, when rotated forward or back in different combinations, create patterns (Collingwood 1996). This method is suitable for weaving narrow bands such as belts, heading bands for the warp of a warp-weighted loom, or decorative borders for the base textile. Such tablet-woven borders are technically complex, extremely labour-intensive and time-consuming.

(C) Antiquity Publications Ltd, 2017 

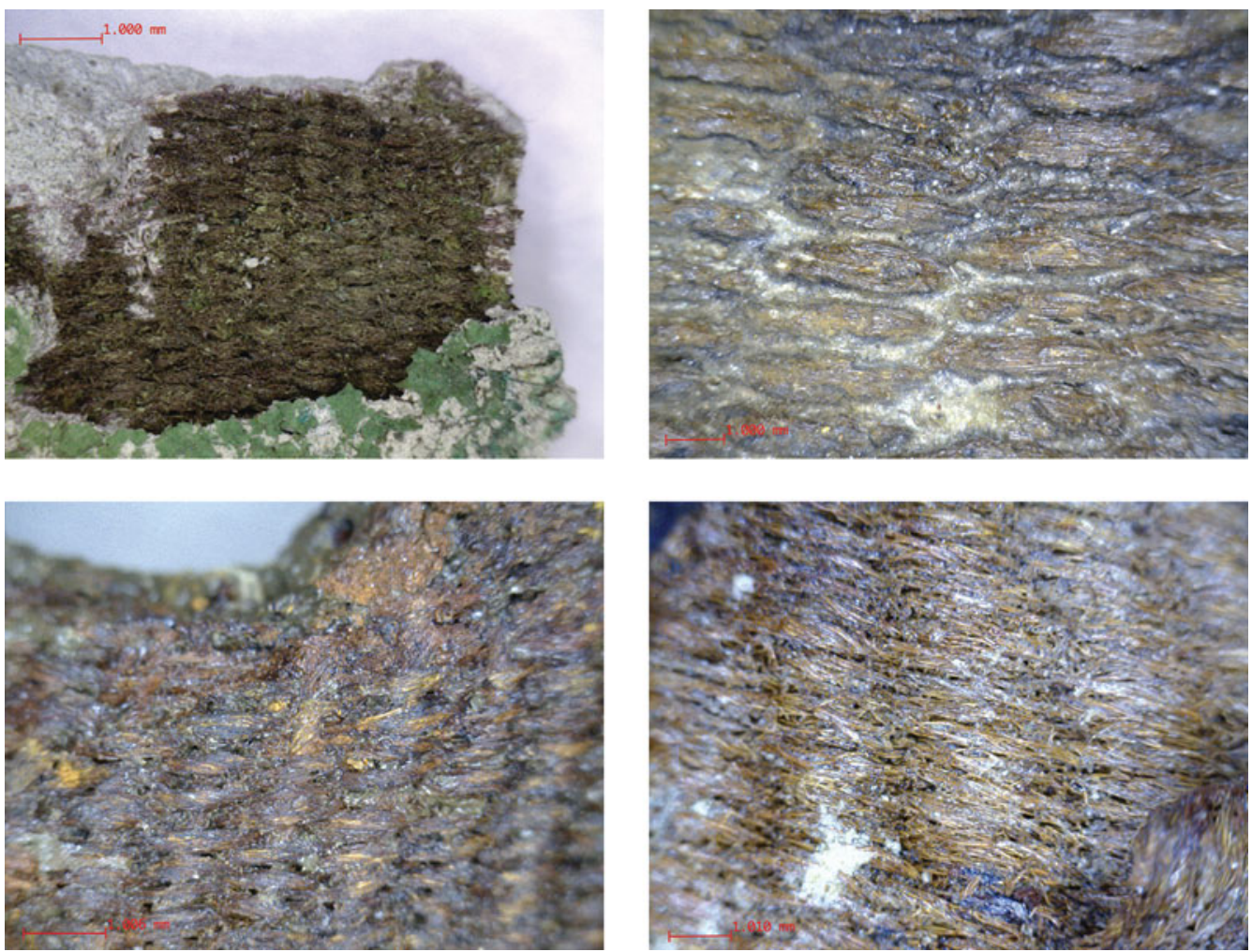

Figure 6. Selection of weft-faced tabbies from Italy: top left) Cumae, eight century BC; top right) Palestrina, seventh century $B C$; bottom left) Alfedena, seventh century BC; bottom right) Ripacandida, sixth century BC (images: Margarita Gleba).

Borders are well illustrated in Etruscan and Italic representational material (Bonfante 2003). They were not purely decorative, but communicated a very clear and important message of status not only to the Italic populations, but also among other European Early Iron Age cultures, in particular the Hallstatt and later La Tène cultures. This is demonstrated by the sophisticated tablet-woven textiles found in the salt mines at Hallstatt and Dürnberg in Austria, and in princely burials at Eberdingen-Hochdorf in Germany and Altrier in Luxembourg (Raeder Knudsen 1999; Grömer et al. 2013: 81-83; Rast-Eicher \& Vanden Berghe 2015). The textiles must have served as indicators of social rank or as 'ceremonial' clothes, with the border constituting the distinguishing element characterised by technique, pattern and colour.

The colour of the mineralised textiles is unknown, but dye analysis of some of the organically preserved finds indicates the use of sophisticated dyeing methods and a variety of plant dye sources, including muricid shellfish for purple, madder for red, woad for blue and a variety of yellow dyes (Vanden Berghe 2002; Vanden Berghe \& Gleba forthcoming). Apart from shellfish purple, all of these sources have also been identified in the Hallstatt textiles (Grömer et al. 2013: 135-62).

In addition, textiles were probably decorated with various beads, buttons and appliqués in precious materials, such as bronze, gold, amber, glass and faience, found in their hundreds

(C) Antiquity Publications Ltd, 2017 
Table 1. Iron Age textiles of Italy: twills ( $\mathrm{x}$ indicates presence; - indicates absence; ? indicates uncertainty due to fragmentary survival). N.B.: more than one textile with these features has been found at many of the sites listed.

\begin{tabular}{|c|c|c|c|c|c|c|}
\hline Site & Area & Date & Twill & $\begin{array}{c}\text { Tablet-woven } \\
\text { borders }\end{array}$ & $\begin{array}{c}\text { Spin } \\
\text { pattern }\end{array}$ & Source \\
\hline Este & Palaeoveneto & eighth-sixth centuries BC & $\mathrm{x}$ & $\mathrm{x}$ & $\mathrm{x}$ & Gleba-unpublished data \\
\hline Santa Palomba & Latium & ninth-eighth centuries BC & $\mathrm{x}$ & $\mathrm{x}$ & $\mathrm{x}$ & Gleba-unpublished data \\
\hline Grotte di Castro & Etruria & eighth century BC & $\mathrm{x}$ & ? & $\mathrm{x}$ & Gleba \& Laurito 2015 \\
\hline Incoronata-S. Teodoro & Oenotria & eighth century BC & $\mathrm{x}$ & ? & $\mathrm{x}$ & Gleba_-unpublished data \\
\hline Cerveteri & Etruria & eighth century BC & $\mathrm{x}$ & ? & - & Gleba_-unpublished data \\
\hline Verucchio & Etruria padana & seventh century BC & $\mathrm{x}$ & $\mathrm{x}$ & $\mathrm{x}$ & Ræder Knudsen 2012; Stauffer 2012 \\
\hline Poggio Aguzzo di Murlo & Etruria & seventh century BC & $\mathrm{x}$ & $\mathrm{x}$ & ? & Gleba_unpublished data \\
\hline Vulci, Tomba delle Mani d'Argento & Etruria & seventh century BC & $\mathrm{x}$ & $\mathrm{x}$ & $\mathrm{x}$ & Guida et al. 2014 \\
\hline Civita Castellana & Faliscan & seventh century BC & $\mathrm{x}$ & $\mathrm{x}$ & $\mathrm{x}$ & Gleba_-unpublished data \\
\hline Osteria dell'Osa & Latium & seventh century BC & $\mathrm{x}$ & $\mathrm{x}$ & $\mathrm{x}$ & Gleba_-unpublished data \\
\hline Palestrina & Latium & seventh century BC & $\mathrm{x}$ & $\mathrm{x}$ & $\mathrm{x}$ & Gleba_-unpublished data \\
\hline Orvieto-Crocifisso del Tufo & Etruria & seventh-sixth centuries BC & $\mathrm{x}$ & $\mathrm{x}$ & $\mathrm{x}$ & Gleba_-unpublished data \\
\hline Chianciano-Tolle & Etruria & seventh-sixth centuries BC & $\mathrm{x}$ & $\mathrm{x}$ & $\mathrm{x}$ & Gleba_-unpublished data \\
\hline Belmonte & Picenum & sixth century BC & $\mathrm{x}$ & ? & - & Gleba-unpublished data \\
\hline
\end{tabular}



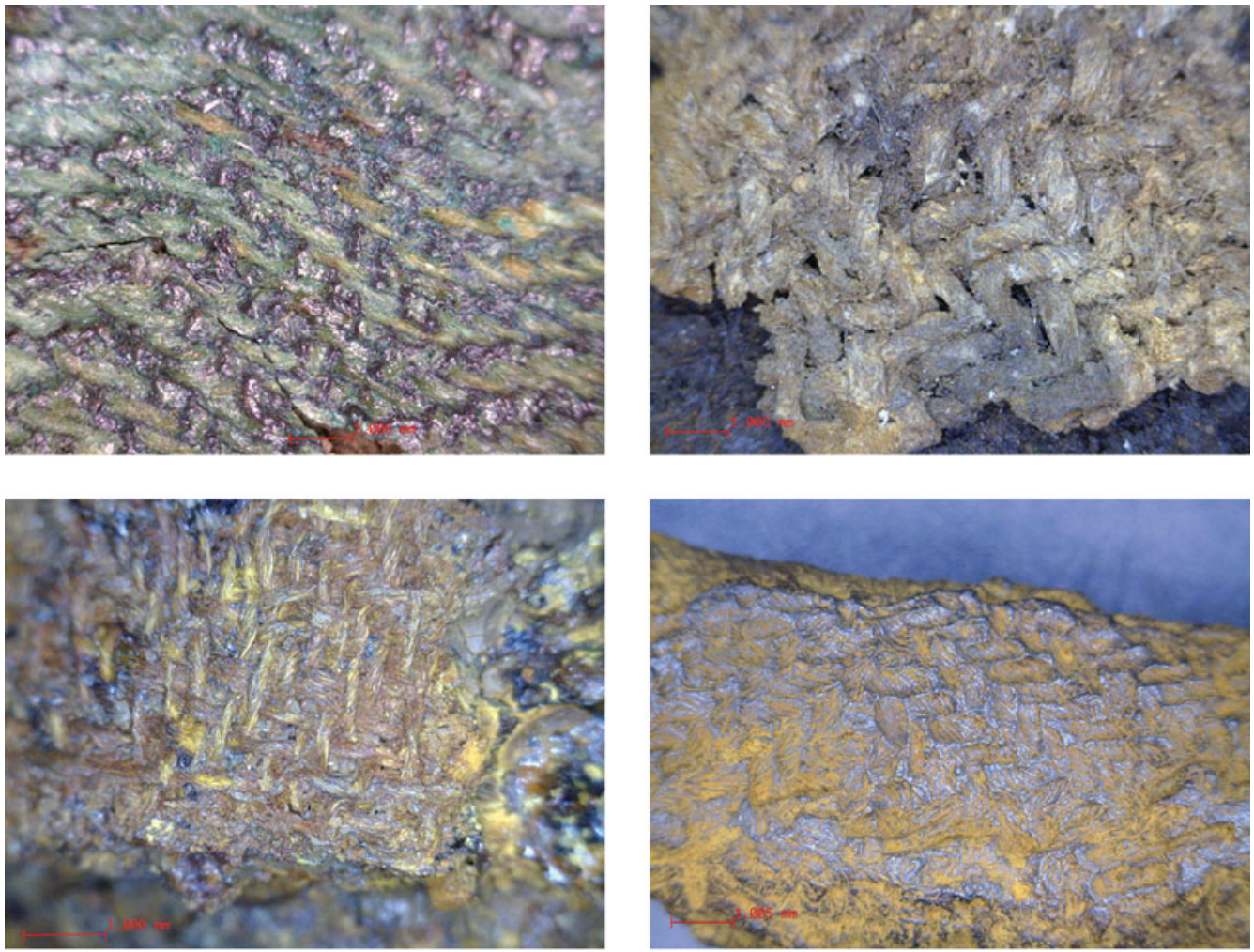

Figure 7. Selection of twills from Italy: top left) Incoronata, eighth century BC; top right) Grotte di Castro, seventh century $B C$; bottom left) Civita Castellana, seventh century BC; bottom right) Chianciano, seventh century BC (images: Margarita Gleba).

and even thousands in rich Iron Age tombs across Italy. Small domed bronze buttons are particularly common over a very wide geographic area. These often preserve the remains of spliced linen threads that were used to attach them to the fabric and possibly arrange them in patterns, as observed in the rosettes, triangles and other elements from the Hallstatt grave in Stična, modern-day Slovenia (Hellmuth 2010).

The wide distribution of these highly decorated twills indicates that Italian populations from Veneto to Basilicata were familiar with the same complex textile technologies that allowed the creation of textiles with a rather distinct appearance. Evidence from Central Europe demonstrates that the Eastern Hallstatt elite also consumed very similar textiles: there is an almost infinite variety of dyed and patterned twills woven in single yarns. Many of the twills are spin patterned (Bender Jørgensen (1992: 122) defined spin-patterned twills as "Vače type"); and although tablet weaves are not integral to the textiles, they were sewn onto the garments and probably served a similar purpose (Grömer et al. 2013). Small domed bronze buttons, similar to those found in Italian burials, and probably used for textile decoration, are also found in large quantities in Hallstatt burials. This similarity is hardly surprising, as Central Europe and Italy had developed close cultural ties during the preceding millennia—a point well proven by the research on the Similaun Man (also known as the Iceman or Ötzi). 

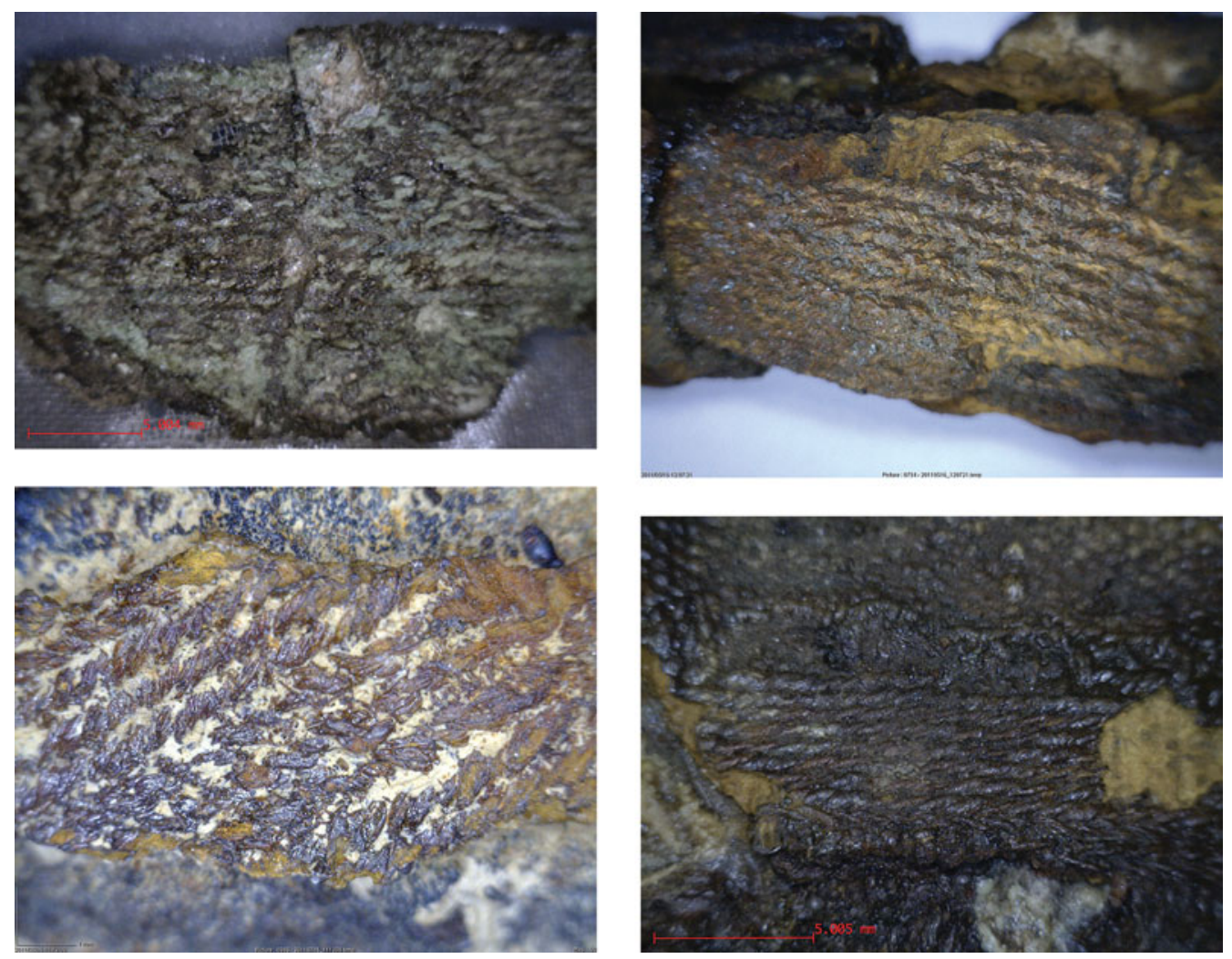

Figure 8. Selection of tablet weaves from Italy: top left) Santa Palomba, eleventh century BC; top right) Osteria dell'Osa, seventh century BC; bottom left) Poggio Aguzzo di Murlo, seventh century BC; bottom right) Alfedena, seventh to sixth century BC (images: Margarita Gleba).

Recent excavations in the Bronze Age mines of Hallstatt have yielded some of the earliest twills and dyed textiles known in Europe (Grömer et al. 2013: 60, 142), and possible evidence for tablet weaving and spin pattern in Central Europe dating back to at least 1500 BC (Grömer et al. 2013: 72, 82). This indicates that the suite of technical and aesthetic attributes ascribed to Central European-Italian textile culture had a long tradition and was well established (and even entrenched) by the beginning of the Iron Age. Where these techniques developed is another question, as there are no extant textiles from Italian contexts contemporaneous with the Bronze Age Hallstatt material. The sophistication of the Italian twills from the eighth-century BC burials and the recent discovery of a complex tablet-woven textile in an eleventh-century BC tomb at Santa Palomba, Rome (De Santis et al. 2010; Figure 8), with a triangular pattern similar to those of the Iron Age Hallstatt tablet bands (Grömer et al. 2013: 451, 483, 520), points to a well-established and settled technology.

\section{Textile culture of Greece 1000-400 BC}

When considering the surviving textiles from Greece dated to 1000-400 BC, a very different picture emerges. All of the textiles discovered thus far are tabbies or weft-faced (C) Antiquity Publications Ltd, 2017 

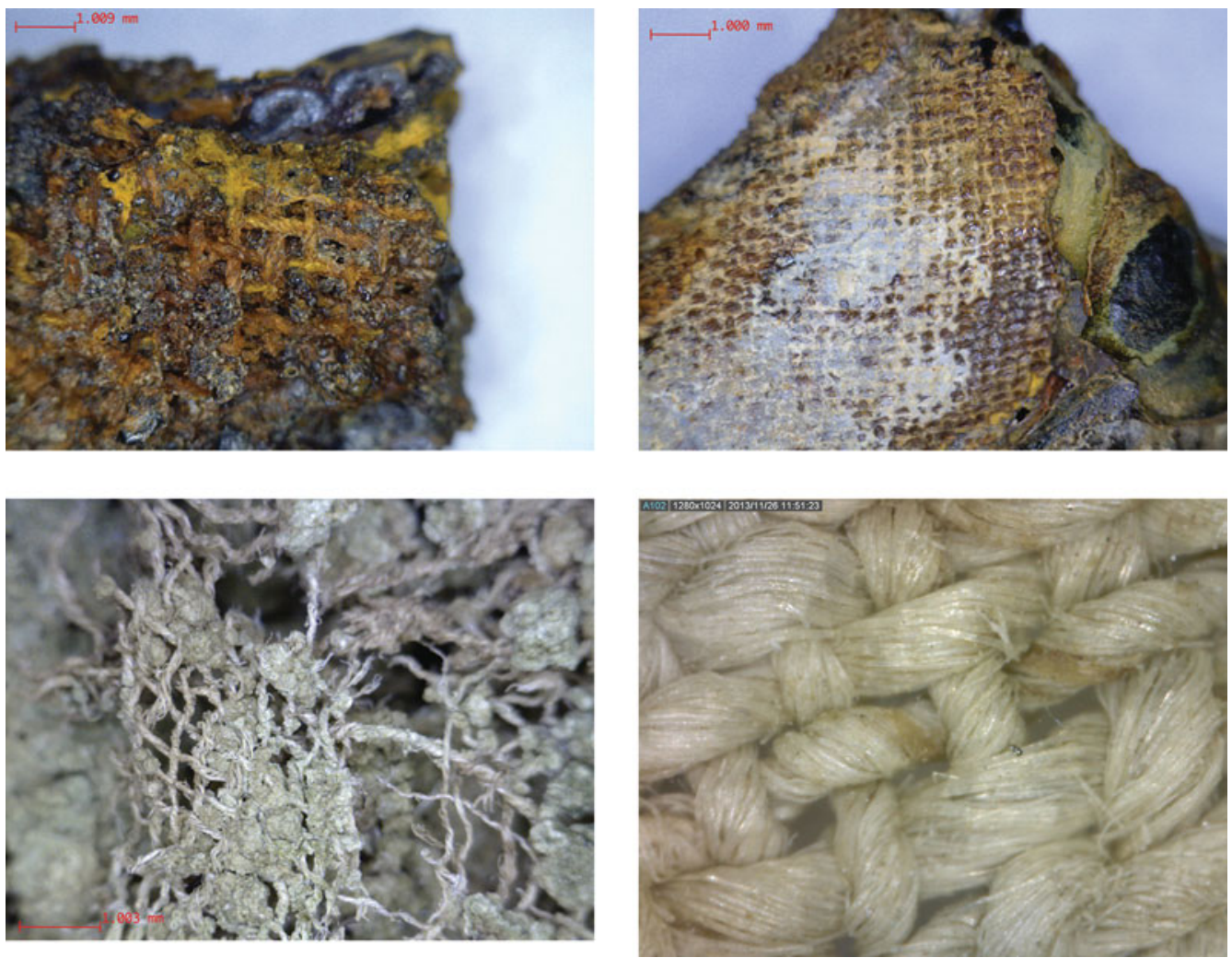

Figure 9. Selection of tabbies from Greece: top left and right) Knossos, eighth century BC; bottom left) Eretria, seventh century BC; bottom right) Athens, Koropi, fifth century BC (images: top left and right and bottom left) Margarita Gleba with permission of the British School at Athens; bottom right) Margarita Gleba with permission of the VerA).

tabbies (Figures 4, 9-10). While many of the balanced tabbies are linen, the raw material of the weft-faced tabbies, where identified, is wool. Most of the weft-faced tabbies have a weft thread count reaching 50 and, in some cases, 100 threads per centimetre (Table 2, Figure 10). The weft threads usually have only weak twist or do not have any discernible twist at all, and weft diameters are often less than $0.2-0.1 \mathrm{~mm}$. While seemingly simple in their basic structure, production of such weft-faced tabbies would have required considerable skill and prime materials.

To date, there is no direct evidence from Greece of spin- or shadow-patterning using alternating groups of $\mathrm{z}$ - and s-twisted threads, and no examples of tablet weaving have been so far identified in extant textiles. Variation and decoration was introduced by varying thread diameter, twist and twist angle (e.g. at Lefkandi-Spantidaki \& Moulhérat 2012: $192,194)$, or through additive techniques, such as embroidery, dyeing or the addition of appliqués (Spantidaki 2014). There is, in fact, more variation in thread-twist combination in weft-faced tabbies in Greece than in Italy.

Weft-faced tabbies are known from the Near East and Egypt during the Bronze Age and certainly during the Iron Age. In the Late Bronze Age royal burial in Qatna, Syria, for

(C) Antiquity Publications Ltd, 2017 
Table 2. Iron Age textiles of Greece: weft-faced tabbies ( $\mathrm{x}$ indicates presence; - indicates absence. N.B.: more than one textile with these features has been found at many of the sites listed).

\begin{tabular}{|c|c|c|c|c|c|c|}
\hline Site & $\begin{array}{l}\text { Cultural } \\
\text { region }\end{array}$ & Date & $\begin{array}{l}\text { Weft- } \\
\text { faced } \\
\text { tabby }\end{array}$ & $\begin{array}{l}\text { Weft thread count } \\
\text { over } 50 \text { threads/ } \\
\text { centimetre }\end{array}$ & $\begin{array}{l}\text { Weft shows } \\
\text { weak or no } \\
\text { twist }\end{array}$ & Source \\
\hline Lefkandi & Euboea & tenth-ninth centuries BC & $\mathrm{x}$ & $\mathrm{x}$ & $\mathrm{x}$ & Spantidaki \& Moulhérat 2012: 191 \\
\hline Stamna & Aitolia & tenth century BC & $\mathrm{x}$ & $\mathrm{x}$ & $\mathrm{x}$ & Kolonas et al. in press \\
\hline Athens & Attica & ninth century BC & $\mathrm{x}$ & $\mathrm{x}$ & $\mathrm{x}$ & Spantidaki \& Moulhérat 2012: 194 \\
\hline Knossos & Crete & tenth-seventh centuries BC & $\mathrm{x}$ & $\mathrm{x}$ & $\mathrm{x}$ & Cocking 1996; Gleba_-unpublished data \\
\hline Kerkyra/Corfu & Corfu & seventh century BC & $\mathrm{x}$ & $\mathrm{x}$ & $\mathrm{x}$ & Spantidaki \& Moulhérat 2012: 191 \\
\hline Argos & Argolid & seventh century BC & $\mathrm{x}$ & - & $\mathrm{x}$ & Margariti \& Papadimitriou 2014 \\
\hline Vergina & Macedonia & sixth century BC & $\mathrm{x}$ & - & $\mathrm{x}$ & Spantidaki \& Moulhérat 2012: 195 \\
\hline Karabournaki & Macedonia & sixth century BC & $\mathrm{x}$ & $\mathrm{x}$ & $\mathrm{x}$ & Cutler \& Gleba 2014 \\
\hline Kamatero & Attica & fifth century BC & $\mathrm{x}$ & $\mathrm{x}$ & $\mathrm{x}$ & Spantidaki \& Moulhérat 2012: 198 \\
\hline Kalyvia & Attica & fifth century BC & $\mathrm{x}$ & $\mathrm{x}$ & $\mathrm{x}$ & Spantidaki \& Moulhérat 2012: 198 \\
\hline
\end{tabular}



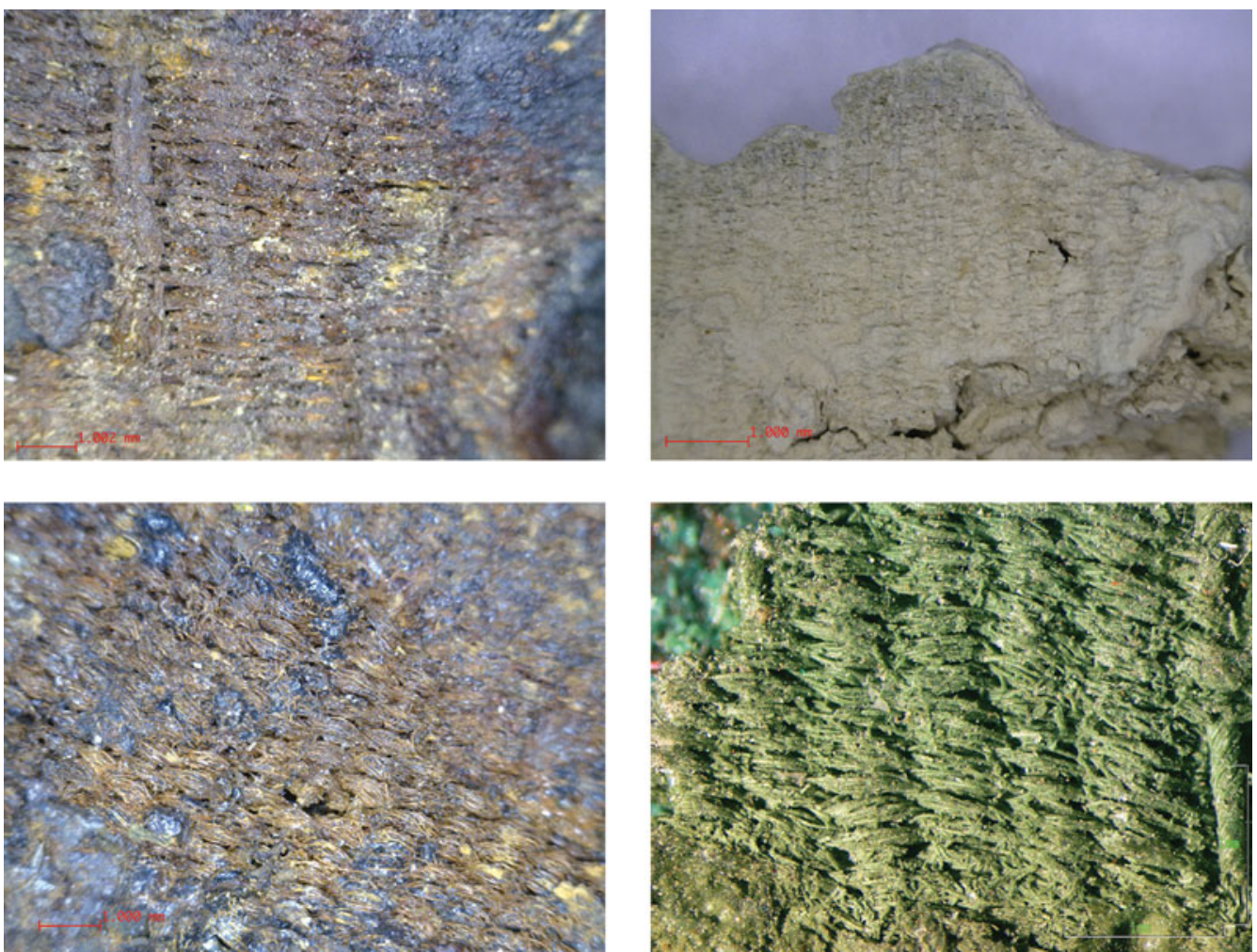

Figure 10. Selection of weft-faced tabbies from Greece: top left) Knossos, eighth century BC; top right) Eretria, seventh century $B C$; bottom left) Karabournaki, sixth century BC; bottom right) Corfu, sixth century $B C$ (images: top left and right) Margarita Gleba with permission of the British School at Athens; bottom left) Joanne Cutler and Margarita Gleba; taken courtesy of the Trustees of the British Museum; bottom right) Artex).

example, several of the identifiable textile fragments are weft-faced tabbies, although their weft thread counts are lower than those of first-millennium BC Greek examples (Reifarth \& Drewello 2011). Apart from one balanced tabby, the 62 analysed wool textiles found at the mining sites of Timna in south-east Israel, which date to the thirteenth to tenth centuries BC, are all weft-faced tabbies with weft counts reaching 40 threads/centimetre (Shamir \& Baginski 1993). Of the 114 textile fragments analysed from the Iron Age (1100-800 BC) levels at Hasanlu in north-west Iran, 69 were weft-faced tabbies, and 8 were weft-faced tabbies with supplementary pile/loop or weft patterning. The remainder were balanced tabbies or basket weaves-i.e. no twills (Love 2011).

Weft-faced tabby is also one of the techniques used for making tapestries, in which the wefts of different colours are woven back and forth to fill in just those areas where these particular colours are needed for the design, and packed so that the warp is not visible. Such tapestry-woven textiles are known since the Middle to Late Bronze Age; for example, in the previously mentioned royal burial at Qatna (James et al. 2009), and in Egypt (Vogelsang-Eastwood 2000: 275). The technique, however, probably developed earlier and is particularly associated with Minoan and Mycenaean cultures of the Bronze

(C) Antiquity Publications Ltd, 2017 
Age Aegean, which left wall paintings depicting spectacularly colourful patterned garments. Actual examples of slit tapestry have been found at Gordion, a Phrygian site in central Turkey, destroyed in the late ninth century BC (Ellis 1981: 305, 310). The Late Assyrian coffin of a female from Ur in southern Iraq, dated to the late eighth to early seventh centuries $\mathrm{BC}$, also contained a fragment of tapestry, possibly in linen and wool but with only the linen surviving (Granger-Taylor 1983: 94)

It therefore appears that, in contrast to the Iron Age textile culture of Italy, Iron Age Greece was much more closely related to the Near Eastern, rather than Central European, tradition. This is, again, hardly surprising, as close connections existed between these areas long before the first millennium BC. A more interesting observation is that this tabby-based textile culture appears to have spread westwards in the early first millennium $\mathrm{BC}$ as part of direct or indirect Hellenisation.

\section{The spread of Greek textile culture}

From the seventh century BC onwards, southern Italy experienced Greek settlement along its littoral from the Ionian Sea in the east to the Tyrrhenian coast in the west.

Although a beautiful chevron twill was identified in an eighth-century BC burial at the indigenous site of Incoronata-San Teodoro, the vast majority of textiles from the late seventh- and sixth-century BC indigenous sites, such as Chiaromonte and Ripacandida, are fine weft-faced tabbies with thread counts reaching 40-50 threads/centimetre, and with weft threads often showing little or no discernible twist and under $0.2 \mathrm{~mm}$ in diameter. More data on the pre-colonial period in this region is needed to establish firmly that these weft-faced tabbies are connected with the arrival of Greek technology. It is, however, telling that the oldest weft-faced tabby identified in Italy so far comes from Cumae, one of the earliest Greek settlements on the peninsula, and has technical characteristics that suggest it is an import (Gleba \& Vanden Berghe in press). Furthermore, finds from Ripacandida may indicate the development of a new, hybrid textile culture: these are weft-faced tabbies with integral tablet-woven borders (Gleba $e t a l$. in preparation). They thus combine what is a typically 'Greek' weave structure with a typically 'Italic' border. As noted above, these borders were not purely decorative, but served as indicators of status and rank. Their importance is emphasised by the fact that local Italic populations, while adapting the new textile weave from their Greek neighbours, were compelled to retain these borders in the production process.

The predominance of weft-faced tabbies in central Adriatic Italy, on the other hand, appears to agree with the generally accepted Adriatic- or Balkan-looking trends in the local material culture. The question remains whether the weft-faced tabbies were developed locally, or were introduced as part of the wider 'Panadriatic' package at the beginning of the Iron Age (Nijboer 2011: 6).

\section{Discussion}

So how can these two apparently contradictory facts be reconciled? There is overwhelming evidence for frequent contact within Italy and between Italy and Greece during the first (C) Antiquity Publications Ltd, 2017 
half of the first millennium BC; the evidence presented here, however, suggests that, in this closely connected region, textile traditions that were technically, aesthetically and conceptually different co-existed. The nature of textile craft, its acquisition patterns and its conservatism may help to explain this.

During the Iron Age, the archaeological evidence points to the development of new or more effective production processes, standardisation and the manufacture of objects for specific purposes in the Mediterranean area. Such transformations occurred primarily under the patronage of elites and were motivated by their desire to produce status markers and prestige goods. Textiles were undoubtedly among the most important of these status markers, being a medium that perhaps made up the largest proportion of the visual environment in antiquity.

The display of luxury and prestige goods, as evidenced by the archaeological record, is closely mirrored in the behaviour of the Iron Age aristocracies and reflects the ideological system underlying their beliefs and values. The common culture and ideology is also reflected in the burial customs of these elites, indicating that the horizontal ties that bound people of similar social status were as important, if not more so, than the vertical ties linking them with their own communities.

Among these elites, textiles circulated over short and long distances in various ways. They were traded, exchanged as gifts, constituted part of a dowry or bride price, were dedicated at sanctuaries, used to pay ransom, taken as booty and even given as prizes in competitions (Gleba 2014b: 83-89). Movement of textiles, tools and women was instrumental in the transfer of textile-related know-how involving ideas, symbols, inventions, fashions, values and, consequently, the technology associated with them.

In all these modes of information-transfer the primary requirement is that the weaver can 'read' the 'technology of transfer' (Gleba 2014b: 94-97). Regarding textile technology, technical expertise would require an extended period of apprenticeship under the supervision of a skilled craftsperson. Hence, the modes of information transmission, which do not involve a person possessing the full knowledge of a particular craft or technique, would only work among users of similar technologies. The transfer of new techniques or patterns between communities using the same type of loom (e.g. a warpweighted loom in the northern Mediterranean) would be more probable than between populations using different types of loom.

The copying of motifs or fashions does not, however, result in the wholesale adoption of a new technique. The transfer of technologies would only work if the audience were receptive. Thus, although Italy and Greece shared similar technologies during the Iron Age - the low-whorl drop spindle for spinning yarn, and the warp-weighted loom for weaving cloth-with a few exceptions, weft-faced tabbies are only present in the central Adriatic region of Italy and in the south of Italy. Here, they probably became popular with the arrival of Greek settlers, who brought with them their own textile culture. Prior to this, Italy mostly shared the textile culture of Central Europe, while Greece largely followed the Near Eastern traditions of textile production. Production of these different textile types would have had aesthetic, but also organisational and labour, implications, as the resources, time and labour consumed by the various stages of the chaîne opératoire would have differed. 
After the sixth century BC, significant changes are notable in the production and consumption of textiles in Italy, although an exploration of this is beyond the scope of the present study. As in other forms of material culture (Nijboer 2011: 18), albeit with some delay, Italy shifted its orientation from Central Europe towards the Eastern Mediterranean, in what has long been described as the Orientalising revolution.

It is also curious that weft-faced tabby became the preferred weave of the Romans (Hero Granger-Taylor pers. comm.), which suggests that with the Romanisation of Italy, Greek tabby textile culture eventually supplanted the indigenous Italic twill tradition. Twills were made on the northern fringes of the Roman Empire and imported to Rome and other Roman provinces, including Egypt, but were seen as part of a 'barbarian' fashion. Borders were, however, retained as important markers of status, as seen in the toga, the Roman descendant of the Verucchio mantles, in which the width of the purple-dyed border continued to signify its wearer's rank. The end of the first millennium $\mathrm{BC}$ thus sees the amalgamation of the two textile cultures that, since the Bronze Age, distinguished the appearance of ancient Greek and Italian populations.

\section{Acknowledgements}

The research leading to these results received funding from the European Research Council under the European Union's Seventh Framework Programme (FP/2007-2013-312603), and was carried out within the scope of the project Production and Consumption: Textile Economy and Urbanisation in Mediterranean Europe 1000-500 BCE. Access to material was kindly provided by the Superintendencies for the Archaeological Heritage of Abruzzo, Basilicata, Lazio and Etruria Meridionale, Roma, Toscana, Umbria and Veneto in Italy; the Ministry of Culture and Sports in Greece; the British Museum, UK; and the Museum of Natural History in Vienna, Austria. I am grateful to Jean MacIntosh Turfa, Susanna Harris, John Robb and Joanne Cutler for commenting on the early drafts of this article, and to the reviewers for providing useful comments.

\section{References}

BeNDER Jørgensen, L. 1992. North European textiles until $A D$ 1000. Aarhus: Aarhus University Press.

Bonfante, L. 2003. Etruscan dress. Baltimore (MD): Johns Hopkins University Press.

Chen, H.L., K.A. Jakes \& D.W. Foreman. 1998. Preservation of archaeological textiles through fibre mineralization. Journal of Archaeological Science 25: 1015-21. https://doi.org/10.1006/jasc.1997.0286

Cocking, J. 1996. Textile remains, in J. Carington-Smith, W.G. Cavanagh, J.M. Cocking, R.D.G. Evely, R.A. Higgins, R.J. Howell, D.J. Liddy, E. Moignard, J.H. Musgrave, N. Platon, A.M. Snodgrass, D. Smyth, S. Wall-Crowther \& V.E.S. Webb, Knossos north cemetery early Greek tombs. Volume II. Discussion: 613-20. London: British School at Athens.

Collingwood, P. 1996. The techniques of tablet weaving. McMinnville (OR): Robin and Russ Handweavers.
Cutler, J. \& M. Gleba. 2014. Appendix: a preliminary study of the textile fragment on GR 1919, 11-19.8. Appendix to C. Morgan, 'A fifth-century BC grave group from Karabournaki in the British Museum', in P. Valavanis \& E.

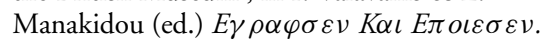
Essays on Greek pottery and iconography in honour of Professor Michalis Tiverios: 253. Thessaloniki: Studio.

De Santis, A., O. Colacicchi, M.R. Giuliani \& B. SANTORo. 2010. Il processo storico nel Lazio antico tra la tarda età del bronzo e la prima età del ferro: i protagonisti, in N. Negroni Catacchio (ed.) Atti XI. Preistoria e Protostoria in Etruria. L'alba dell'Etruria. Fenomeni di continuità e trasformazione nei secoli XII-VIII a.C. Ricerche e scavi: 311-26. Milano: Centro Studi di Preistoria e Archeologia.

ElLis, R. 1981. Appendix 5, in R.S. Young, Gordion excavation reports, volume I: three great early tumuli (P, $M M, W)$. Philadelphia (PA): University Museum.

GLEBA, M. 2008. Textile production in pre-Roman Italy (Ancient Textile Series 4). Oxford: Oxbow. 


\section{Tracing textile cultures of Italy and Greece in the early first millennium BC}

- 2014a. Wrapped up for safe keeping: 'wrapping' customs in Early Iron Age Europe, in S. Harris \& L. Douny (ed.) Wrapping and unwrapping material culture: archaeological and anthropological perspectives: 135-46. Walnut Creek (CA): Left Coast.

- 2014b. Cloth worth a king's ransom: textile circulation and transmission of textile craft in the ancient Mediterranean, in K. Rebay-Salisbury, L. Foxhall \& A. Brysbaert (ed.) Material crossovers: knowledge networks and the movement of technological knowledge between craft traditions: 83-103. New York: Taylor \& Francis.

Gleba, M. \& S. Harris. In press. Plant fibre technology: identifying splicing in archaeological textiles. Archaeological and Anthropological Sciences.

Gleba, M. \& R. Laurito. 2015. Appendice 1. Analisi delle tracce di tessuti rinvenuti a Grotte di Castro in località Vigna la Piazza, in E. Pellegrini, Un aspetto delle necropoli etrusche di Grotte di Castro: le tombe a fossa con circolo di Vigna La Piazza: 265-67; and appendix in Annali Faina XX: 337-39, 346.

Gleba, M. \& I. Vanden Berghe. In press. Textiles from Cumae Fondo Artiaco 104: structural and dye analyses, in A. Babbi, Jahrbuch des Römisch-Germanischen Zentralmuseums.

Gleba, M., C. Heitz, H. Landenius Enegren \& F. Meo. In preparation. At the crossroads of textile cultures: textile production and use at the south Italian Archaic site of Ripacandida. Journal of Mediterranean Archaeology.

Granger-Taylor, H. 1983. The textile fragments from PG16, in J. Curtis, Late Assyrian Bronze coffins. Anatolian Studies 33: 94-95.

Grömer, K., A. Kern, H. Reschreiter \& H. Rösel-Mautendorfer (ed.). 2013. Textiles from Hallstatt. Weaving culture in Bronze and Iron Age salt mines. Textilien aus Hallstatt. Gewebte Kultur aus dem bronze- und eisenzeitlichen Salzbergwerk (Archaeolingua 29). Budapest: Archeolingua.

Guida, G., M.R. Giuliani \& S. Ferrari. 2014. I metalli e i materiali tessili, in S. Carosi \& P. Petitti (ed.) Principi immortali. Fasti dell'aristocrazia etrusca a Vulci: 51-58. Roma: Gandemi.

Harris, S. 2012. From the parochial to the universal: comparing cloth cultures in the Bronze Age. European Journal of Archaeology 15: 61-97. https://doi.org/10.1179/1461957112Y. 0000000006

Hellmuth, A. 2010. Zur Rekonstruktion des Prunkgewandes aus Stična Grab 27, Grabhügel48/K rekonstrukciji razkošnega oblačila iz stiškega groba 27 v gomili 48 , in S. Gabrovec \& B. Teržan (ed.) Stična II/2 Gomile starejše železne dobe/Grabhügel aus der Älteren Eisenzeit (Katalogi in Monografije 38): 61-68. Ljubljana: Narodni Muzej.
James, M.A., N. Reifarth, A.J. Mukherjee, M.P. Crump, P.J. Gates, P. Sandor, F. Robertson, P. Pfälzner \& R.P. Evershed. 2009. High prestige royal purple dyed textiles from the Bronze Age royal tomb at Qatna, Syria. Antiquity 83: 1109-18. https://doi.org/10.1017/S0003598X00099397

Killen, J.T. 2007. Cloth production in Late Bronze Age Greece: the documentary evidence, in C. Gillis \& M.-L. Nosch (ed.) Ancient textiles: production, craft and society. Proceedings of the First International Conference on Ancient Textiles, held at Lund, Sweden, and Copenhagen, Denmark, on March 19-23, 2003 (Ancient Textiles Series 1): 50-58. Oxford: Oxbow.

Kolonas, L., K. Sarri, I. Skals, C. Margariti $\&$ M.-L. Nosch. In press. Protogeometric funerary textiles from Stamna, Aitolia, Greece, in Hesperos. The Aegean seen from the West. $16^{\text {th }}$ International Aegean Conference. University of Ioannina, 16-21 May 2016.

Love, N. 2011. The analysis and conservation of the Hasanlu-period IVB textiles, in M. de Schauensee (ed.) People and crafts in period IVB at Hasanlu, Iran: 43-56. Philadelphia: University of Pennsylvania Museum.

Margariti, C. \& A. Papadimitriou. 2014. Material identification and technological analysis of a $7^{\text {th }}$-century BC excavated textile from Argos, Greece. Archaeological Textiles Review 56: 14-23.

McCorriston, J. 1997. The fibre revolution: textile extensification, alientation, and social stratification in ancient Mesopotamia. Current Anthropology 38: 517-49. https://doi.org/10.1086/204643

Nijboer, A.J. 2011. Italy, its interconnections and cultural shifts during the Iron Age, in H. Di Giuseppe \& M. Dalla Riva (ed.) Atti XVII Congresso Internazionale di Archeologia Classica; Incontri tra Culture nel Mondo Mediterraneo Antico: 1-22. Rome: AIAC.

Ræder Knudsen, L. 1999. Technical description of the fragments of the broad tablet woven band found on the big cauldron from Eberdingen-Hochdorf, in J. Banck-Burgess, Hochdorf IV: 80-82. Stuttgart: Theiss.

- 2012. The tablet-woven borders of Verucchio, in M. Gleba \& U. Mannering (ed.) Textiles and textile production in Europe from prehistory to $A D 400$ : 254-65. Oxford \& Oakville (CT): Oxbow.

Rast-Eicher, A. \& I. Vanden Berghe. 2015. Altrier-a new look on the textiles, in K. Grömer \& F. Pritchard (ed.) Aspects of the design, production and use of textiles and clothing from the Bronze Age to the early modern era. NESAT XII: 117-24. Budapest: Archaeolingua. 


\section{Margarita Gleba}

Reifarth, N. \& R. Drewello. 2011. Textile Spuren in der Königsgruft. Vorbericht zu ersten Ergebnissen und dem Potenzial zukünftiger Forschungen, in P. Pfälzner (ed.) Interdisziplinäre Studien zur Königsgruft von Qatna (Qatna Studien 1): 469-82. Wiesbaden: Harrassowitz.

RIva, C. 2010. The urbanisation of Etruria: funerary practices and social change, 700-600 BC. Cambridge: Cambridge University Press.

Shamir, O. \& A. Baginski. 1993. Textiles from the mining camps and Timna. Archaeological Textiles Newsletter 15: 6.

Spantidaki, S. 2014. Embellishment techniques of Classical Greek textiles, in M. Harlow \& M.-L. Nosch (ed.) Greek and Roman textiles and dress: an interdisciplinary anthology: 34-45. Oxford: Oxbow.
Spantidaki, Y. \& C. Moulhérat. 2012. Greece, in M. Gleba \& U. Mannering (ed.) Textiles and textile production in Europe from prehistory to $A D 400$ : 185-200. Oxford \& Oakville (CT): Oxbow.

Stauffer, A. 2012. Case study: the textiles from Verucchio, Italy, in M. Gleba \& U. Mannering (ed.) Textiles and textile production in Europe from prehistory to $A D$ 400: 242-53. Oxford \& Oakville (CT): Oxbow.

Vanden Berghe, I. 2002. Appendice 1: analisi del colore, in P. von Eles, Guerriero e sacerdote. Autorità e comunità nell'età del ferro a Verucchio. La Tomba del Trono: 220. Firenze: All'Insegna del Giglio.

VAnden Berghe, I. \& M. Gleba. Forthcoming. Dyes and dyeing in Italy during the first millennium BCE. Journal of Archaeological Science.

Vogelsang-Eastwood, G. 2000. Textiles, in P.T. Nicholson \& I. Shaw (ed.) Ancient Egyptian materials and technology: 268-95. Cambridge: University of Cambridge Press.

Received: 5 August 2016; Accepted: 3 November 2016; Revised: 15 November 2016

(C) Antiquity Publications Ltd, 2017 